\title{
Paraedwardsia hadalis, a new ultra-abyssal sea anemone (Actiniaria: Edwardsiidae) from Aleutian Trench
}

\author{
N.P. Sanamyan, K.E. Sanamyan
}

Kamchatka Branch of Pacific Geographical Institute, Far-Eastern Branch of the Russian Academy of Sciences, Partizanskaya 6, Petropavlovsk-Kamchatsky, 683000, Russia. E-mail: actiniaria@sanamyan.com

ABSTRACT: Ultra-abyssal Paraedwardsia hadalis sp.n. is a first species of sea anemones described from Aleutian Trench. It resembles two deep water species $P$. abyssorum and $P$. lemchei which differ from other Paraedwardsia species by weak development of tenaculi. Paraedwardsia hadalis sp.n. from $7250 \mathrm{~m}$ is a most deep water species of the family Edwardsiidae.

How to cite this article: Sanamyan N.P., Sanamyan K.E. 2018. Paraedwardsia hadalis, a new ultra-abyssal sea anemone (Actiniaria: Edwardsiidae) from Aleutian Trench // Invertebrate Zoology. Vol.15. No.1. P.42-50. doi: 10.15298/invertzool.15.1.03

KEY WORDS: Sea anemone, Actiniaria, Aleutian Trench, Edwardsiidae, Paraedwardsia.

\section{Paraedwardsia hadalis, новая ультраабиссальная актиния (Actiniaria: Edwardsiidae) из Алеутского желоба}

\section{Н.П. Санамян, К.Э. Санамян}

Камчатский филиал Тихоокеанского института географии ДВО РАН, ул. Партизанская, 6, Петропавловск-Камчатский 683000, Россия. E-mail: actiniaria@sanamyan.com

РЕЗЮМЕ: Ультраабиссальный вид Paraedwardsia hadalis sp.n. является первой актинией, описанной из Алеутского желоба. Он сходен с двумя глубоководными видами, $P$. abyssorum and $P$. lemchei, которые отличаются от других видов рода Paraedwardsia слабым развитием тенакулей. Paraedwardsia hadalis sp.n., найденная на глубине 7250 м, является самым глубоководным из известных видов в семействе Edwardsiidae.

Как цитировать эту статью: Sanamyan N.P., Sanamyan K.E. 2018. Paraedwardsia hadalis, a new ultra-abyssal sea anemone (Actiniaria: Edwardsiidae) from Aleutian Trench // Invertebrate Zoology. Vol.15. No.1. P.42-50. doi: 10.15298/invertzool.15.1.03

КЛЮЧЕВЫЕ СЛОВА: Морские анемоны, Actiniaria, Алеутский желоб, Edwardsiidae, Paraedwardsia. 


\section{Introduction}

Very few sea anemones are known from deep water trenches. Carlgren (1956) described six species from the depths exceeding 6000m: Galatheanthemum hadale Carlgren, 1956, G. profundale Carlgren, 1956, Paraedwardsia lemchei Carlgren, 1956, Daontesia mielchei Carlgren, 1956, Bathydactylus kroghi Carlgren, 1956 and Hadalanthus knudseni Carlgren, 1956. Galatheanthemum profundale was reported subsequently from many deep water trenches (Cairns et al., 2007) while all other species listed above are known from original descriptions only. Paraedwardsia hadalis sp.n. is a first sea anemone reported from Aleutian trench. In addition, at our disposal is also a specimen of Actinernus, collected at $6057 \mathrm{~m}$ in the western end of Aleutian trench, south off Commander Islands, but this material is not published yet.

\section{Material and methods}

The specimens were collected by $\mathrm{R} / \mathrm{V}$ "Vityaz" in 1969, preserved in alcohol and stored in the Institute of Oceanology (Moscow). The methods of preparation of histological sections, measuring size ranges of cnidae and cnidae terminology are the same as in our previous papers (e.g. Sanamyan et al., 2012, 2013). The specimens will be deposited in Zoological Museum of Moscow State University (ZMMU).

\section{Taxonomy}

\author{
Order Actiniaria \\ Family Edwardsiidae Andres, 1881 \\ Paraedwardsia Carlgren in Nordgaard, 1905 \\ Paraedwardsia hadalis sp.n. \\ Table 1; Figs. 1-5.
}

MATERIAL EXAMINED. Holotype: ZMMU Ec-114, R/V "Vityaz", cruise 45, station 6145 , depth $7250 \mathrm{~m}, 51^{\circ} 09.7^{\prime} \mathrm{N}, 174^{\circ} 35.5^{\prime} \mathrm{E}$, 20 June 1969, one specimen. Paratypes: ZMMU Ec-115, same data, two specimens.

DESCRIPTION. Three available specimens were in a very good condition (Fig. 1A). The largest specimen is $16 \mathrm{~mm}$ in height and $9 \mathrm{~mm}$ in diameter was designated as holotype. Two other specimens, $10 \times 5.5 \mathrm{~mm}$ and $13.5 \times 7 \mathrm{~mm}$ were designated as paratypes. The latter specimen had better preserved cuticle and ectoderm and was used for histological sections. The body is pear-shaped with wide round aboral end, divisible into physa, scapus, scapulus and very short capitulum. The distal part of the column is contracted and deeply invaginated; the tentacles, the capitulum, the scapulus and the distal part of the scapus are not visible from exterior in all specimens. The body wall is thin and eight mesenterial insertions are visible. Contracted retractors with filaments and gonads are located in proximal part of the body (Fig. 1B). The mesogloea of the scapus and physa is about $30-45 \mu \mathrm{m}$ in thickness. The endoderm is about $25 \mu \mathrm{m}$ in thickness and the thickness of the ectoderm varies from 1-2 to 50-70 $\mu \mathrm{m}$ in numerous "protuberances" and patches of thickened ectoderm (Fig. 1C). Some of these high protuberances of the ectoderm are supported by mesogloeal strands and resemble tenaculi (Fig. 1D). The scapus is covered by thin (about $1 \mu \mathrm{m}$ ) gray-brown cuticle encrusted by fine sediment, but not by sand grains and other solid particles. Nemathybomes are not present. The cuticle and the ectoderm is partly abraded (Fig. 1A) and because of this the border between the physa and the scapus is not clear. However, on histological sections, the physa is differentiated from the scapus by smooth surface of the ectodermal side of the mesogloea. A ring of eight (?) tiny apertures were observed in one specimen (intact paratype) but we failed to demonstrate them on histological sections. The scapulus is not covered by cuticle, it has eight high, up to $800-900 \mu \mathrm{m}$, mesogloeal ridges between the insertions of the macrocnemes (Figs. 1B, 2A). These mesogloeal ridges extend to invaginated part of the scapus. Very short thin-walled capitulum (the thickness of the mesogloea is 3-6 $4 \mathrm{~m}$ ) is just at the bases of the tentacles (Fig. 1B). Circular endodermal columnar muscles are well developed.

The tentacles (Fig. 2B), 12 in number, arranged into two cycles, 9 tentacles are in the outer ring and 3 tentacles are in the inner ring, 
Table 1. Size ranges (length $\times$ width, in microns) and distribution of cnidae of Paraedwardsia hadalis sp.n. Letters in brackets correspond to letters in Fig. 5. Frequencies given are subjective impressions based on all the cnidae seen on the slides.

Таблица 1. Размеры (длина $\times$ ширина, в микронах) и распределение стрекательных капсул Paraedwardsia hadalis sp.n. Буквы в скобках соответствуют буквам на рис. 5. Частота встречаемости дана как субъективное впечатление, основанное на всех книдах, найденных на препаратах.

\begin{tabular}{llll}
\hline Body region & Cnidae & $\begin{array}{l}\text { Size ranges }(\mu \mathrm{m}) \\
\text { (holotype) }\end{array}$ & $\begin{array}{l}\text { Size ranges }(\mu \mathrm{m}) \\
\text { (paratypes) }\end{array}$ \\
\hline Physa & Basitrichs (rare) & $17-21 \times 2-3$ & - \\
\hline Scapus & (A) basitrichs (common) & $25-48 \times 2.5-3$ & $23-35 \times 3-4$ \\
& $($ B) holotrichs (few) & - & $7-9 \times 2.5$ \\
\hline Scapulus & $(\mathrm{C})$ basitrichs (common) & $15-18 \times 2-2.5$ & $14-19 \times 2-2.5$ \\
\hline Capitulum & Basitrichs (common) & - & $16-20 \times 2-3$ \\
\hline Tentacles & (D) gracile spirocysts (numerous) & $15-35 \times 2-5$ & $18-30 \times 2.5-4$ \\
& (E) robust spirocysts (numerous) & $18-41 \times 3-7$ & $13-41 \times 3.5-6$ \\
& (F) basitrichs (common) & $33-70 \times 2-3$ & $35-46 \times 3-3.5$ \\
\hline Actinopharynx & $(\mathrm{G})$ basitrichs (common) & $24-50 \times 2.5-3$ & $34-40 \times 2.5-3$ \\
\hline Filaments & (H) basitrichs (common) & $33-43 \times 2.5-3$ & $33-48 \times 3-3.5$ \\
& (I) p-mastigophores A (common) & $21-28 \times 4-6$ & $23-28 \times 5-6$ \\
\hline Endoderm of & (J) basitrichs (few) & $15-16 \times 5($ only & $15-21 \times 4-5.5$ \\
all body & & in mesenteries) & \\
regions & & & \\
\hline
\end{tabular}

one of which arise from endocoel of ventral directives (not visible on Fig. 2B) and two from endocoels of the dorso-lateral pairs of mesenteries. Longitudinal muscles of the tentacles (Fig. 1E) and radial muscles of the oral disc are ectodermal. The mesogloea on the tips of the tentacles is very thin.

The actinopharynx is rather short, has no recognizable siphonoglyphs. It has eight high longitudinal mesogloeal ridges corresponding to insertions of the macrocnemes. Four highest ridges, up to $250 \mu \mathrm{m}$, correspond to lateral macrocnemes and four smaller, up to $150 \mu \mathrm{m}$, correspond to directives. Insertions of the microcnemes are marked by small ridges, up to 50 $\mu \mathrm{m}$ (Fig. 2C). At aboral end of the actinopharynx the mesogloeal ridges continue into cnidoglandular tracts of the trilobate filaments, while the ectoderm of the adjacent regions of the actinopharynx form ciliate tracts (Fig. 2F). Reticular tract of the trilobate filaments is derived from endoderm of the actinopharynx. The filaments are present on all macrocnemes.
Eight macrocnemes are arranged as in all Edwardsiids and present along the whole length of the body. Four microcnemes paired with lateral macrocnemes are present in the distal part of the body. They appear at the most distal part of the scapus and extend through the whole length of the scapulus (Fig. 2A), capitulum and present at the distal part of the actinopharynx (Fig. 2C, D). On the transverse sections on the level of the distal part of the actinopharynx the microcnemes are rather long (Fig. 2C) and have a layer of fine non branched longitudinal muscles on their ventral sides (i.e. facing to exocoels) (Fig. 4E). In the region of the scapulus and capitulum the microcnemes have flap-like mesogloeal thickening on the ventral side. In these regions the microcnemes are lined by fine muscle fibers which are expanded on the body wall (Fig. 4D).

Retractor muscles on macrocnemes are restricted, with 17-22 muscle processes, few of them are weakly branched but many are not. There are no pennons or free flaps on retractors. 

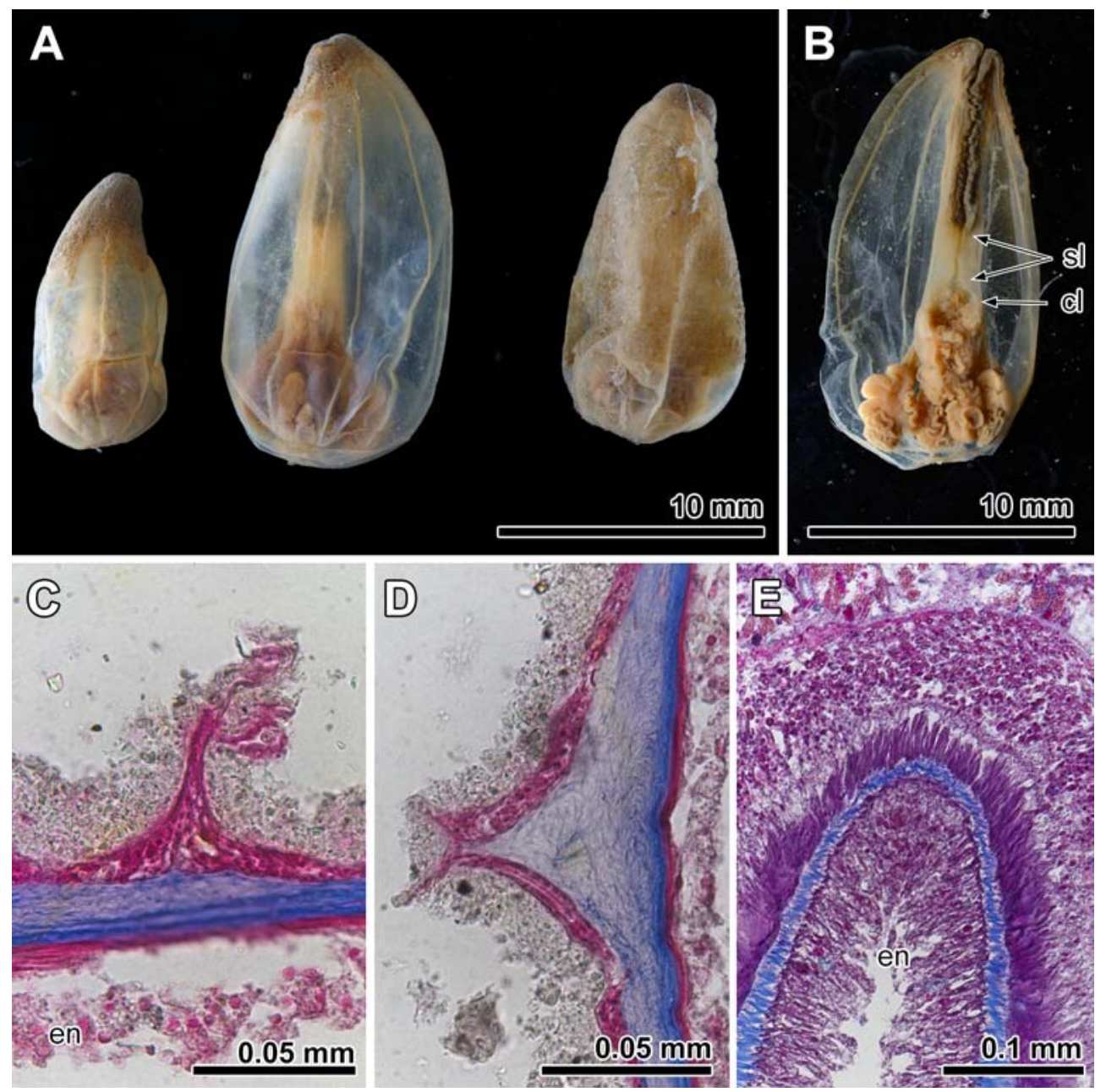

Fig. 1. Paraedwardsia hadalis sp.n. A — intact specimens; B — larger specimen dissected longitudinally (holotype); $\mathrm{C}$ - ectodermal protuberance on the scapus; D - tenacule-like structure on the scapus; E longitudinal ectodermal muscles of the tentacle.

Abbreviations: $\mathrm{cl}$ - capitulum; en - endoderm; $\mathrm{sl}$ - scapulus.

Рис. 1. Paraedwardsia hadalis sp.n. А - фиксированные экземпляры; В - продольный срез самого крупного экземпляра (голотип); C - складка эктодермы на скапусе; D - тенакуле-подобная структура на скапусе; Е - продольная эктодермальная мускулатура щупальца.

Сокращения: cl - капитулюм; en - энтодерма; sl - скапулюс.

The retractors are situated closer to the actinopharynx (Fig. 2C-F) and attached to the body wall by thin lamellae. At the region of physa the retractors become smaller and the mesogloeal lamella connecting the retractors and the parietal muscles become shorter (Fig. 4B) and disappears completely in the most proximal part of the mesenteries (Fig. 4C). The parietal muscles have different appearance in the different regions of the body (Figs. 3, 4A-D). They first appear at the region of capitulum as a thickening of the mesenterial mesogloea lined with longitudinal muscle fibers (Fig. 3A). Toward the scapulus tiny mesogloeal muscle processes become apparent. In this region the parietal muscles are not symmetrical, better developed on the same 


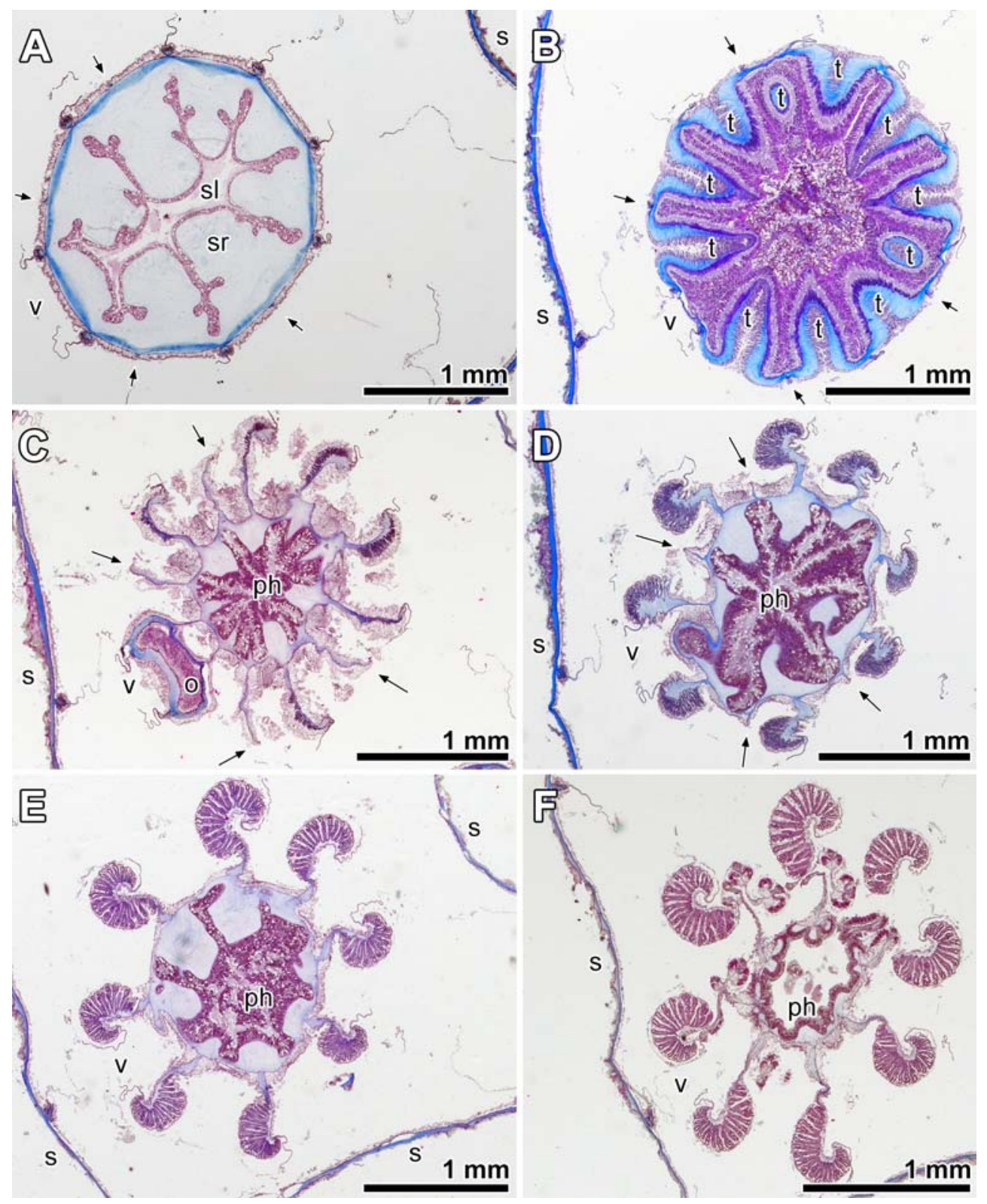

Fig. 2. Paraedwardsia hadalis sp.n., paratype, transverse sections. A - scapulus, introverted; B - section on the level of the tentacles; $\mathrm{C}-\mathrm{D}$ - distal part of the actinopharynx; E - middle part of the actinopharynx; $\mathrm{F}$ - proximal end of the actinopharynx.

Abbreviations: $\mathrm{o}$ - oral disc; $\mathrm{ph}$ - actinopharynx; $\mathrm{s}$ - scapus; $\mathrm{sl}$ - scapulus; $\mathrm{sr}$ - scapular ridge; $\mathrm{t}$ - tentacles; $\mathrm{v}$ - ventral pair of the directives; arrows point to microcnemes.

Рис. 2. Paraedwardsia hadalis sp.n., паратип, поперечные срезы. А - ввернутый скапулус; В - срез на уровне щупалец; $\mathrm{C}-\mathrm{D}$ - дистальная часть глотки; $\mathrm{E}$ - средняя часть глотки; $\mathrm{F}$ - проксимальный конец глотки.

Сокращения: o - оральный диск; $\mathrm{ph}$ - глотка; s - скапус; sl - скапулюс; sr - скапулярный гребень; $\mathrm{t}$ щупальца; $\mathrm{v}$ - вентральная пара направляющих мезентериев; стрелками указаны микромезентерии. 

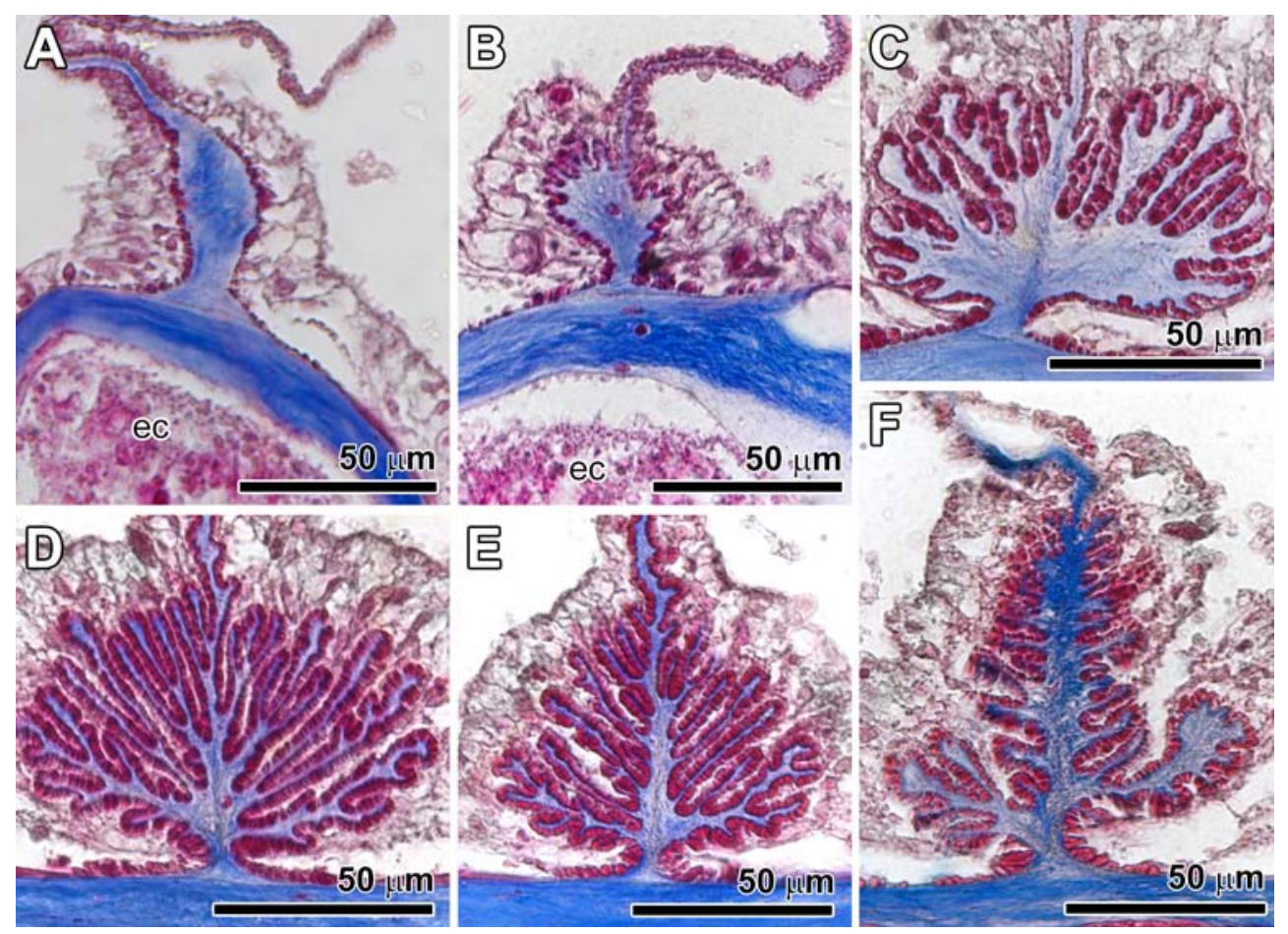

Fig. 3. Paraedwardsia hadalis sp.n., paratype, parietal muscles of the macrocnemes. A - in the capitulum; $\mathrm{B}$ - in the distal end of the scapulus; $\mathrm{C}$ - in the scapulus; D-E - in the middle part of the scapus; F in the proximal part of the scapus.

Abbreviations: ec - ectoderm.

Рис. 3. Paraedwardsia hadalis sp.n., паратип, париетальные мускулы макромезентериев. А - в капитулюме; В — в районе дистального конца скапулюса; C - в скапулюсе; D-E - в средней части скапуса; F - в проксимальной части скапуса.

Сокращения: ес - эктодерма.

side as retractor (Fig. 3B). In the scapulus the parietal muscles are symmetrical and fan shaped (Fig. 3C). In the middle part of the scapus muscle processes are more branched (Fig. 3D) and parietal muscles are triangular on transverse sections (Fig. 3E). In the proximal part of the body parietal part of the mesentery covered by parietal muscles gradually become longer (on transverse sections), its mesogloea become thicker and muscle processes become shorter (Fig. 3F). At the region of physa parietal muscles form small, up to $10 \mu \mathrm{m}$, but recognizable flap from the side opposite to retractor (Fig. 4A-B). Parietal muscle fibers are expanded on the body wall.

Two sectioned specimens were males. On the smaller specimen gonads are present on four lateral macrocnemes but we failed to find them on directives. On the larger specimen (holotype) gonads are present on directives too. Spermatozoa are about 3-3.5 $\times 2-2.5 \mu \mathrm{m}$, tip headed, symmetrical, with wide mitochondrial complex (Fig. 4F).

Cnidom includes spirocysts, holotrichs, basitrichs, p-mastigophores A (Tab. 1, Fig. 5). Small sparse holotrichs in the ectoderm of the scapus (Fig. 5B) were detected only on histological sections but we failed find them on macerated samples of ectoderm from the scapus of all three specimens. Basitrichs of the capitulum and endoderm of all regions of the body (Fig. $5 \mathrm{~J}$ ) were seen in histological sections only (in paratype). Ectoderm of the oral disc contains spirocysts and basitrichs (recorded on histolog- 


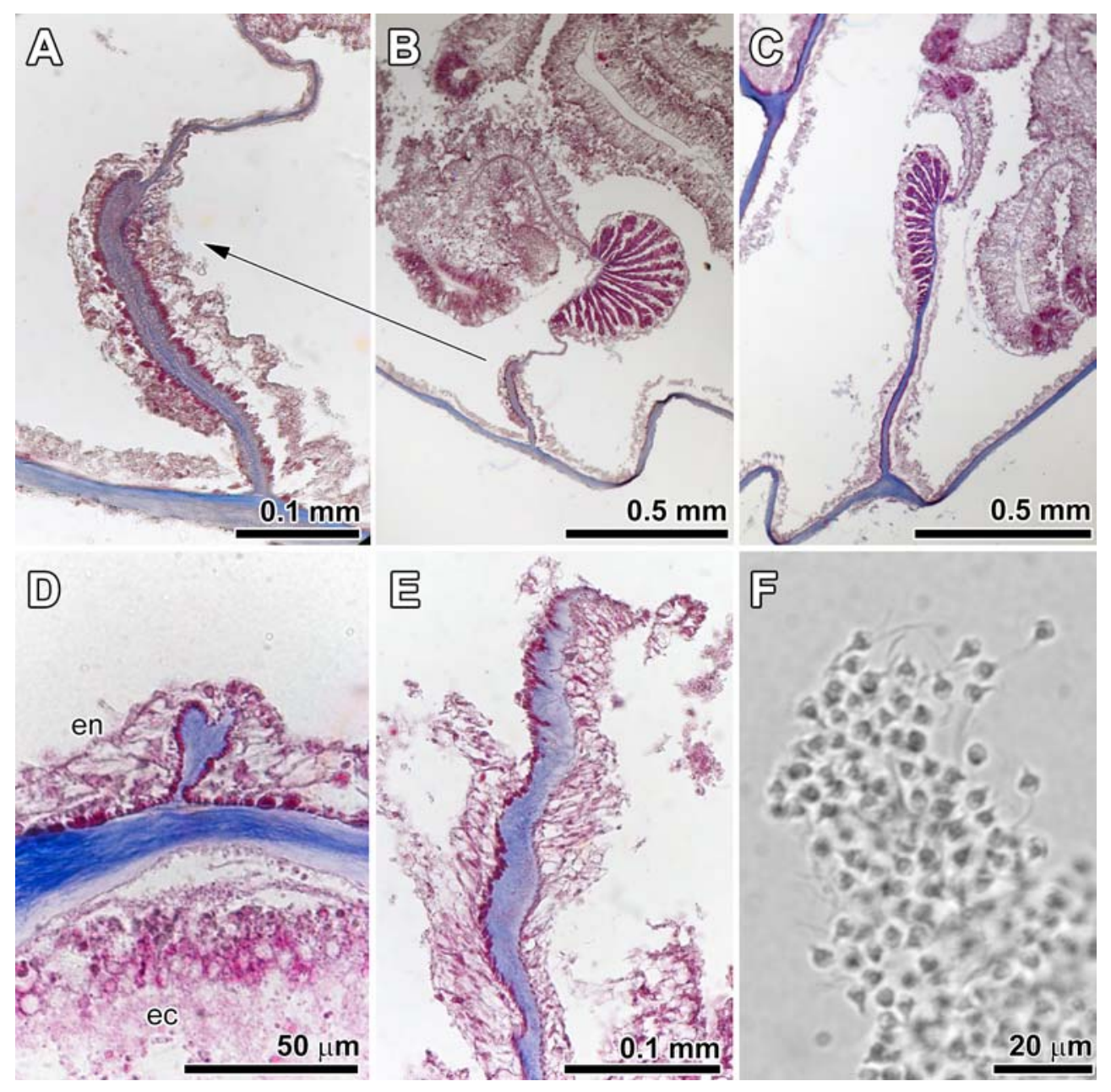

Fig. 4. Paraedwardsia hadalis sp.n. A - parietal part of the macrocneme in the physa; $\mathrm{B}-\mathrm{C}$ - macrocnemes in the physa; D - microcneme in the capitulum; E - microcneme on the level of distal part of the actinopharynx; F - spermatozoa (from holotype).

Abbreviations: ec - ectoderm; en - endoderm.

Pис. 4. Paraedwardsia hadalis sp.n. А — париетальная часть макромезентерия на уровне физы; В-C макромезентерии на уровне физы; D - микромезентерий в капитулюме; Е - микромезентерий на уровне дистальной части глотки; $\mathrm{F}$ - сперматозоиды (из голотипа).

Сокращения: ес — эктодерма; еn — энтодерма.

ical sections). We failed to find p-mastigophores in the actinopharynx of two dissected specimens (distal, middle and proximal parts of actinopharynx were examined).

REMARKS. The most significant features of the described here species are the absence of nemathybomes, weak development of tenacules and the presence of only 12 tentacles. The arrangement of the tentacles is identical to those shown by Manuel (1988, Fig. 72) for Edwardsia ivelli Manuel, 1975. The present record from $7250 \mathrm{~m}$ is a most deep water known record of a species belonging to the family Edwardsiidae. Edwardsiidae is a diverse family comprising about 70 species most of which are known from shallow and moderate depths. Very few abyssal 


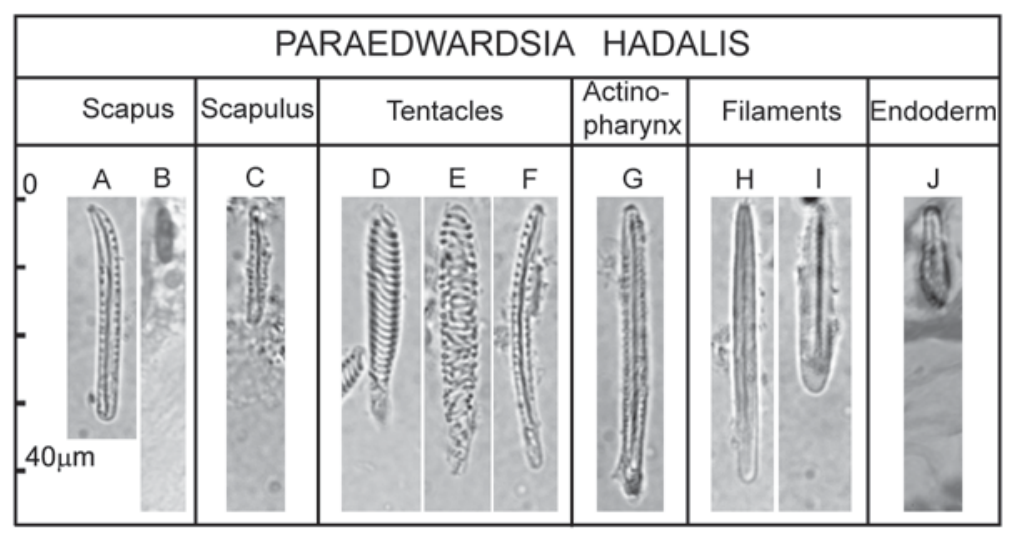

Fig. 5. Paraedwardsia hadalis sp.n., distribution of cnidae (see Table 1 for size ranges).

Рис. 5. Paraedwardsia hadalis sp.n., распределение книд (размеры указаны в табл. 1).

edwardsiids are known, two of them belong to the genus Edwardsia (E. mcmurrichi Daly et Ljubenkov, 2008 and E. sojabio Sanamyan et Sanamyan, 2012) and three to Paraedwardsia (P. abyssorum Carlgren, 1951, P. lemchei Carlgren, 1956 and $P$. heia Daly et Ljubenkov, 2008).

The genus Paraedwardsia comprises six valid species. Its members differ from the members of much more diverse genus Edwardsia by the presence of tenaculi in the scapus and by the absence of nemathybomes, nematocyst bearing structures characteristic for Edwardsia and Scolanthus.

Two most deep-water Paraedwardsia species, $P$. abyssorum and $P$. lemchei, differ from other members of the genus by weak development of tenaculi. Carlgren $(1951,1956)$ failed to find clear tenaculi in these species and referred them to Paraedwardsia provisionally because he has not seen any tenaculi, but wrote that "the numerous mesogloeal papillae indicate that such may have been present" (Carlgren, 1956: 10). The species described here also has poorly developed tenaculi but ectodermal side of the mesogloea forms numerous high strands ("papillae" sensu Carlgren, 1956) and these three species obviously constitute closely related group. In the present paper we follow Carlgren $(1951,1956)$ and despite poorly developed tenaculi, refer the specimens from Aleutian Trench to the genus Paraedwardsia.
COMPARISON WITH OTHER SPECIES OF THE GENUS. Paraedwardsia lemchei is known only from the original description based on numerous specimens from Java Trench, 7160 $\mathrm{m}$. It differs from $P$. hadalis sp.n. by possessing 14-16 tentacles and by the presence of large pmastigophores in the actinopharynx.

Paraedwardsia abyssorum is known only from one poorly preserved specimen from Tropical Atlantic, $5610 \mathrm{~m}$. The number of the tentacles, 12 , is the same as $P$. hadalis sp.n., but retractor muscles appear to be weaker and have recognizable flap (see Carlgren, 1951, Fig. 2), while in $P$. hadalis sp.n. the flap is totally absent. It has small basitrichs in the filaments $(24-28 \times 3 \mu \mathrm{m})$ which not present in the specimens from Aleutian Trench. Although the variability of reported features and the significance of these differences cannot be accessed without examination of additional specimens, we prefer to treat the specimens from Aleutian Trench as distinct from P. abyssorum: the specimens come from too distant locations (North Pacific and tropical Atlantic) and presumably from different environment (abyssal plain for P. abyssorum and deep-water trench for $P$. hadalis sp.n.).

Third deep water species of Paraedwardsia, $P$. heia, described from 2650-3065 m off California(Daly, Ljubenkov, 2008), differs from $P$. hadalis sp.n., by well developed tenaculi (photo of intact specimen shows attached sand 
grains, see Daly \& Ljubenkov, 2008, Fig. 9A), presence of 16 tentacles and much smaller basitrichs in the tentacles.

Other three hitherto known species of Paraedwardsia - P. arenaria Carlgren in Nordgaard, 1905, P. cretata (Stimpson, 1856) and $P$. sarsii (Dueben et Koren, 1847) - are relatively shallow water and do not occur in abyssal depths.

\section{ACKNOWLEDGMENTS}

We are grateful to anonymous referees for useful comments and corrections of the manuscript. The work was partially supported by grant of Russian Foundation for Basic Research (RFBR) 16-04-01685 a.

\section{References}

Cairns S.D., Bayer F.M., Fautin D.G. 2007. Galantheanthemum profundale (Anthozoa: Actiniaria) in the Western Atlantic// Bulletin of Marine Science. Vol.80. No.1. P.191-207.
Carlgren O. 1951. Actiniaria // Reports of the Swedish deep-sea expedition. Vol.2. Zoology. No.8. P.101104.

Carlgren O. 1956. Actiniaria from depths exceeding 6000 meters // Galathea report. Vol.2. Scientific results of the Danish deep-sea expedition round the World 195052. P.9-16.

Daly M., Ljubenkov J.C. 2008. Edwardsiid sea anemones of California (Cnidaria: Actiniaria: Edwardsiidae), with descriptions of eight new species // Zootaxa. Vol.1860. P.1-27.

Manuel R.L. 1988. British Anthozoa // Synopses of the British Fauna (N.S.). London: Academic Press. No.18. $241 \mathrm{p}$.

Sanamyan N., Sanamyan K., McDaniel N. 2013. Two new shallow water sea anemones of the family Actiniidae (Cnidaria: Anthozoa: Actiniaria) from British Columbia (NE Pacific) // Invertebrate Zoology. Vol.9. No.2. P.199-216.

Sanamyan N., Sanamyan K., Tabachnick K. 2012. The first species of Actiniaria, Spongiactis japonica gen.n., sp.n. (Cnidaria: Anthozoa) an obligate symbiont of a glass sponge // Invertebrate Zoology. Vol.9. No.2. P.127-141.

Responsible editor A.Yu. Sinev 